\title{
Heat and temperature metacognition awareness inventory: A confirmatory factor analysis
}

\author{
Moh. Irma Sukarelawan ${ }^{1}$, Dwi Sulisworo ${ }^{2}$, Jumadi $^{3}$, Heru Kuswanto ${ }^{4}$, Siti Anisatur Rofiqah \\ ${ }^{1,2}$ Postgraduate Program of Physics Education, Universitas Ahmad Dahlan, Indonesia \\ ${ }^{1,3,4}$ Postgraduate Program of Physics Education, Universitas Negeri Yogyakarta, Indonesia \\ ${ }^{5}$ Department of Physics Education, STKIP Nurul Huda, Indonesia
}

\begin{tabular}{l} 
Article Info \\
\hline Article history: \\
Received Aug 7, 2020 \\
Revised Feb 21, 2021 \\
Accepted Apr 3, 2021 \\
\hline
\end{tabular}

\section{Keywords:}

Confirmatory factor analysis

Heat and temperature

Maximum likelihood

Metacognition awareness

Problem-solving

\begin{abstract}
This cross-sectional study aimed to validate students' metacognition awareness inventory in Heat and Temperature material. A total of 167 public senior high school students in Yogyakarta, Indonesia were selected through convenience sampling technique. The heat and temperature metacognition awareness inventory (HeTMAI) inventory consists of six factors, namely: 1) Knowledge of cognition; 2) Planning; 3) Monitoring; 4) Evaluation; 5) Debugging; and 6) Information management. HeTMAI used a 5-point Likert scale. The data was analyzed using the confirmatory factor analysis (CFA) method through the Maximum Likelihood approach. All statistics were found to meet acceptance values. The four GOF indices $(\chi 2 / \mathrm{df}=2.36, \mathrm{CFI}=0.97$, $\mathrm{TLI}=0.97$, and SRMR=0.06) have supported the fit of the six-factor HeTMAI model. Standardized factor loading (SFL), construct reliability (CR), average variance extracted (AVE) and discriminant values provide evidence that HeTMAI has sufficient convergent and discriminant validity. Cronbach's alpha value of 0.96 indicated HeTMAI has very adequate evidence of reliability.
\end{abstract}

This is an open access article under the CC BY-SA license.

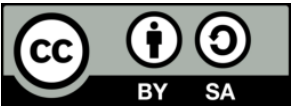

\section{Corresponding Author:}

Moh. Irma Sukarelawan

Postgraduate Program of Physics Education

Universitas Ahmad Dahlan

Umbulharjo, Yogyakarta 55161, Indonesia

Email: moh.sukarelawan@mpfis.uad.ac.id

\section{INTRODUCTION}

Over the decades, most educational institutions have been responsible for the accumulation of knowledge at all levels of education, contributing to the repetition of materials without any logical meaning to learners [1]. Educational institutions are further away from their primary function to solve real problems around them [2]. Today, there is a need that is more important than just mastering content. Educational institutions must equip various skills that lead to problem-solving for students. With this awareness, the Government of Indonesia has formulated the 2013 National Curriculum (called K13) to improve students' problem-solving skills through metacognitive [3].

At the beginning of its appearance, the term metacognition was first introduced by Flavell in the United States in 1976 [4]. Metacognition describes an individual's knowledge related to cognitive activity or everything related to it [5]-[8]. Metacognition is divided into six factors/constructs, namely: 1) Knowledge of Cognition; 2) Planning; 3) Monitoring; 4 Evaluation; 5) Debugging, and 6) Information Management [9]. Knowledge of Cognition is knowledge, ideas, and theories that students have memorized regarding goals and strategies in completing assignments [9], [10]. Knowledge of Cognition contains declarative, procedural, and 
conditional knowledge. Declarative knowledge describes a student's knowledge of himself as a student or as a problem solver. Procedural knowledge describes students' knowledge of how they solve a task or problem. Conditional knowledge describes students' knowledge of when and why to apply the two previous knowledge. This involves the experience of when and why to use a specific solution for a specific problem and execute it. Planning describes a student's ability to plan and set goals before completing a task or problem. Monitoring describes a student's ability to take ongoing action on his goals, work, and performance. Evaluation describes the students' ability to assess the work they have completed. Debugging describes students' ability to use strategies to improve learning, difficulties, and errors in solving problems. Information management describes students' ability to use specific strategies to solve problems more effectively [8], [11].

Metacognitive is an important aspect of successful learning, including learning physics. Various studies have reported a positive metacognitive correlation to academic achievement [7]. Metacognitive helps optimize problem-solving skills for students [4], [12]. Students who have metacognitive awareness become more independent, autonomous, and self-regulated learners, creating a continuous, thoughtful, and strategic learning process [2]. Hence, there has been a significant increase in the number of studies related to this concept since the 1970s [13]. This means metacognitive has become one of the central issues in educational research in Indonesia and around the world for over four decades [7], [10], [14].

As the spearhead of the current curriculum implementation, educators need to map accurately to obtain valid and reliable information [2]. Valid information will be the basis for designing effective and efficient learning activities, evaluating programs, identifying students who need more routine interventions, and evaluating the existing curriculum [3], [7], [13].

Like the previous statement, metacognitive plays an active role in shaping students as problem solvers. However, there are limited studies on the impact of metacognitive on problem-solving abilities in physics. One of the reasons is the limited problem solving-based metacognitive instruments [8], [11]. This is an essential issue since the ability to solve problems determines the quality and advancement of studying physics [15].

Quality instruments play an essential role in data collection. Currently, researchers have developed various instruments to measure metacognitive awareness. Among them are MAI, Jr. MAI Version A and B, MMCI, MSS, MIT, AILI, SMM, MSAS, COMEGAM, Facet MAI, and MS [16]. All reported instruments are general. This means that it does not explicitly lead to problem-solving abilities in physics. Specific instruments will provide more accurate information according to information needs. The tools for measuring metacognition awareness that is devoted to the field of physics are still limited to the best of the author's knowledge and support of [16], primarily targeted at specific materials in physics. Taasoobshirazi and Farley [11] have developed a 24-item physics metacognition inventory (PMI) based on problem-solving abilities. Then in 2015, redeveloped the PMI to be a 26-item [8]. In 2020, Haeruddin, et al. [17] developed a problem solving-based metacognitive instrument (43-item). PMI shows its potential for use in different cultural contexts [18], [19]. However, PMI has not provided more specific information based on the needs of each material in physics. For example, in the Information management constructs (free-body diagram).

In this study, we adapted PMI and then contextualized it on heat and temperature materials. This material is one of the fundamental materials in physics and other sciences [20]. Therefore, to fill in the gaps outlined earlier, this study aims to validate the Heat and Temperature Metacognition Awareness Inventory (HeTMAI) as a screening tool. This study uses a confirmatory factor analysis approach. To achieve the goal, we asked three main research questions: 1) Does HeTMAI have a good overall model fit? 2) Does HeTMAI have sufficient evidence of convergent and discriminant validity? 3) Does HeTMAI have sufficient evidence of reliability?

\section{RESEARCH METHOD}

Data comes from two public senior high schools in Yogyakarta, Indonesia. The sample size used was at least five times more than the number of variables [21]. Moreover, 167 participants consisting of 26\% male and $74 \%$ female from class XI and between the age range of 16-17 years (Average $=16.54, \mathrm{SD}=0.69$ ) were selected using a convenience sampling technique [22].

The 26-item heat and temperature metacognition awareness inventory (HeTMAI) developed from the physics metacognition inventory (PMI) [8], [11]. Instruments translated by English lecturer in the field of applied linguistics. The translation results are then modified on the heat and temperature material to HeTMAI. Test results limited to 10 students did not show any significant problems in HeTMAI.

HeTMAI defines knowledge and attitudes towards metacognitive awareness in physics learning on heat and temperature material. HeTMAI consists of 6 constructs, namely: 1) Knowledge of cognition (KoC), 2) Planning (PL); 3) Information management (INFO); 4) Monitoring (MON); 5) Debugging (DEB); and 6) 
Evaluation (EVA) as shown in Table 1. Students' responses have been collected using a 5-point Likert scale in the range 1 (Never) to 5 (Always).

Table 1. Heat and temperature metacognition awareness inventory

\begin{tabular}{|c|c|c|c|c|c|}
\hline \multirow{2}{*}{ No. } & \multirow{2}{*}{ Statement } & \multicolumn{4}{|c|}{ My condition } \\
\hline & & 1 & 3 & 4 & 5 \\
\hline \multicolumn{6}{|c|}{ Knowledge of cognition (KoC) } \\
\hline 1 & I am confident about my ability to solve heat and temperature problems & & & & \\
\hline 2 & When solving heat and temperature problems, I know how I do it in the best way & & & & \\
\hline 3 & $\begin{array}{l}\text { When solving heat and temperature problems, I know how to apply strategies to solve these } \\
\text { problems well }\end{array}$ & & & & \\
\hline 4 & When solving heat and temperature problems, I have specific goals for each strategy I use & & & & \\
\hline 5 & When solving heat and temperature problems, I know when to use certain strategies & & & & \\
\hline 6 & $\begin{array}{l}\text { When solving heat and temperature problems, I know the reasons for using certain } \\
\text { strategies }\end{array}$ & & & & \\
\hline \multicolumn{6}{|c|}{ Planning (PL) } \\
\hline 7 & I thought about what questions to ask before I started solving them & & & & \\
\hline 8 & $\begin{array}{l}\text { Before solving the heat and temperature problems, I identified all the essential parts of the } \\
\text { problem }\end{array}$ & & & & \\
\hline 9 & $\begin{array}{l}\text { Before solving the heat and temperature problems, I ignore the information that I do not } \\
\text { need in the problem }\end{array}$ & & & & \\
\hline 10 & $\begin{array}{l}\text { Before solving the heat and temperature problems, I think about a reasonable value/result } \\
\text { as the answer }\end{array}$ & & & & \\
\hline 11 & Before I started solving heat and temperature problems, I planned a way to solve them & & & & \\
\hline \multicolumn{6}{|c|}{ Information management (INFO) } \\
\hline 12 & I drew a free-body diagram of the heat and temperature problem I was working on & & & & \\
\hline 13 & I use the free-body diagram to help me solve heat and temperature problems & & & & \\
\hline 14 & I draw the free-body diagram to help me solve heat and temperature problems & & & & \\
\hline 15 & I know the importance of free-body diagrams for solving heat and temperature problems & & & & \\
\hline \multicolumn{6}{|c|}{ Monitoring (MON) } \\
\hline 16 & When I was solving physics problems, I asked myself how well I was doing it & & & & \\
\hline 17 & When solving heat and temperature problems, I sometimes evaluate how well I am doing & & & & \\
\hline 18 & While solving heat and temperature problems, I asked myself if I achieved my goal & & & & \\
\hline 19 & $\begin{array}{l}\text { While solving heat and temperature problems, I ask myself at certain times if I achieved my } \\
\text { goal }\end{array}$ & & & & \\
\hline \multicolumn{6}{|c|}{ Debugging (DEB) } \\
\hline 20 & I ask for help when I do not know about heat and temperature problems & & & & \\
\hline 21 & I seek help if I do not understand the heat and temperature I am handling. & & & & \\
\hline 22 & I changed strategies when I failed to solve the heat and temperature problems & & & & \\
\hline \multicolumn{6}{|c|}{ Evaluation (EVA) } \\
\hline 23 & After solving the heat and temperature problems, I double-checked my answer & & & & \\
\hline 24 & I checked my work again after solving the heat and temperature problems & & & & \\
\hline 25 & $\begin{array}{l}\text { After finishing the heat and temperature problems, I double-checked whether I was doing } \\
\text { the right procedure }\end{array}$ & & & & \\
\hline 26 & $\begin{array}{l}\text { After solving the heat and temperature problem, I looked back at the problem to see if my } \\
\text { answer made sense }\end{array}$ & & & & \\
\hline
\end{tabular}

In this study, students filled out a questionnaire online. It took students about 15 minutes to complete the questionnaire. Data collection time was about four weeks. Student participation is voluntary [8]. Before filling out the questionnaire, we guarantee the confidentiality of the data they provide. We provided opportunities for students to withdraw all responses that have been given without being subject to punishment.

All data that was collected was transferred to IBM SPSS 23. The Lisrel 8.80 program was used to evaluate the validity of HeTMAI. Via the Maximum Likelihood approach, data was analyzed using the Confirmatory Factor Analysis (CFA) method. This was conducted by testing the relationship between the observed variables and construct [23].

Before determining the validity of HeTMAI, it begins with testing the sample size's adequacy and checking the estimation results. Furthermore, the overall model fit test is carried out. After obtaining a good overall model fit, it is continued by testing validity and reliability.

The sample size adequacy test used the KMO-MSA and Bartlett's Test of Sphericity [24]-[28]. The adequacy of the sample size is met if the KMO-MSA value is $>0.6$ and the significance of Bartlett's Test of Sphericity $<0.05$ [21], [29]. The estimation results were checked through the t-value and standardized factor loading (SFL) of each item. The estimated value is accepted if the t-value is $\geq 1.96$ or practically $\geq 2$ and $\mathrm{SFL} \geq 0.45$ [21], [30], [31].

The overall model fit test was associated with standard fit indices or goodness-of-fit (GOF) [31], [32]. However, several indices have been proposed to assess Goodness-of-Fit in the last decade [33]. Since 
this study has 26 observed variables with 167 participants, the GOF standard for HeTMAI referred to five standards, namely: the ratio between Chi-square $\left(\chi^{2}\right)$ and degree of freedom (df), comparative fit index (CFI), Tucker Lewis index (TLI), standardized root means square residual (SRMR) and root mean square error of Approximation (RMSEA). The overall fit of the model is met if a value $\chi 2 / \mathrm{df} \leq 3.00$, CFI and TLI $\geq 0.95$, $\mathrm{SRMR} \leq 0.08$ and $\mathrm{RMSEA}<0.08$ [21], [34]. This index provides evidence of how well the six-factor HeTMAI model is on empirical data. Moreover, it is possible to improve the model's suitability through the simultaneous modification of indices and correlation coefficients during the analysis of the variables [31], [34].

HeTMAI validation is done by presenting evidence of convergent validity and discriminant validity. Convergent validity investigates the extent to which the correlation between two concepts is the same [21]. The evidence of convergent validity is checked through three parameters, namely: 1) Standardized factor loading (SFL); 2) Construct reliability (CR); and 3) Average variance extracted (AVE). The convergent validity is considered good if $S F L \geq 0.45, C R \geq 0.70$ and $A V E \geq 0.50$ [21], [31], [34]. Discriminant validity is used to see the difference between the two constructs conceptually. Discriminant validity is fulfilled if the AVE estimate is higher than the squared correlation between the two constructs [21]. Reliability analysis was conducted using Cronbach's alpha such that values greater than 0.70 indicate acceptable reliability [35] while those above 0.80 are considered to have excellent reliability [36].

\section{RESULTS AND DISCUSSION}

This study was conducted to produce a valid and reliable metacognition awareness inventory to solve heat and temperature problems in physics. The process was empirically validated in public senior high schools using 167 participants.

\subsection{Adequacy of sample size}

The sample size's adequacy was tested using KMO-MSA and Bartlett's Test of Sphericity before the CFA analysis was conducted, and the KMO-MSA value was found to be 0.931 and higher than the predetermined standard. Meanwhile, Bartlett's Test of Sphericity obtained was 3695.142 with a significance of $\mathrm{p}=0.000$ and much smaller than the standard. Based on these two values, HeTMAI met the adequacy of sample size requirements for CFA [37].

\subsection{Estimation results}

An initial analysis of the factor load estimation results was conducted on each of the observed variables using the t-value and SFL before the model's suitability was tested, as shown in the measurement model presented in Table 2. Table 2 shows that there was a not t-value and SFL value below the specified standard. The minimum t-value is 7.62 (PL3) and the maximum is 15.30 (INFO2). Meanwhile, the minimum SFL value is 0.56 (PL3), and the maximum is 0.92 (INFO2). In summary, the initial analysis does not indicate an offending estimate. Therefore, the overall fit analysis of the HeTMAI model can be continued.

Table 2. The initial analysis of the factor load estimation results from the model

\begin{tabular}{lcccccc}
\hline & KoC & PL & INFO & MON & DEB & EVA \\
\hline t-value & $10.86-13.13$ & $7.62-13.02$ & $14.09-15.30$ & $11.64-14.17$ & $9.65-10.94$ & $9.65-14.44$ \\
SFL & $0.74-0.84$ & $0.56-0.82$ & $0.87-0.92$ & $0.78-0.88$ & $0.69-0.76$ & $0.68-0.89$ \\
\hline
\end{tabular}

\subsection{Overall model fit}

Five indices have been used to see the overall fit of the model. The values $\chi 2 / \mathrm{df}$, CFI, TLI, SRMR, and RMSEA usually provide sufficient unique information to evaluate the suitability of the HeTMAI model [21], [30]. The goodness-of-fit indices of the six correlated factors in the HeTMAI model obtained are $\chi 2 / \mathrm{df}=670.63 / 284=2.36, \mathrm{CFI}=0.97, \mathrm{TLI}=0.97, \mathrm{SRMR}=0.06$, and RMSEA=0.09. All indexes, except RMSEA, show a good fit to the model and are acceptable. Although the RMSEA index does not meet the criteria, the SRMR index can replace it because both are indices that represent the badness of fit of the model [21]. Based on the overall model fit assessment, this study has provided clear evidence that HeTMAI is statistically accurate among students in measuring metacognitive awareness. These results reinforce the six-factor model proposed [8].

\subsection{Convergent validity}

The declaration of the model to fit the overall using the GOF indices led to the evaluation of each construct's convergent validity. The specific SFL criteria used was 0.45 concerning the sample size [21], [38]. The results are shown in Table 3. 
Table 3. Convergent validity of HeTMAI

\begin{tabular}{|c|c|c|c|}
\hline \multirow{2}{*}{ Latent variables (Cronbach's alpha) } & \multicolumn{3}{|c|}{ Convergent validity } \\
\hline & SFL & $\mathrm{CR}$ & AVE \\
\hline Factor 1. Knowledge of cognition (0.90) & & 0.91 & 0.62 \\
\hline $\mathrm{KoCl}$ & 0.74 & & \\
\hline $\mathrm{KoC} 2$ & 0.84 & & \\
\hline $\mathrm{KoC} 3$ & 0.82 & & \\
\hline $\mathrm{KoC} 4$ & 0.74 & & \\
\hline $\mathrm{KoC5}$ & 0.80 & & \\
\hline KoC6 & 0.77 & & \\
\hline Factor 2. Planning (0.85) & & 0.87 & 0.58 \\
\hline PL1 & 0.82 & & \\
\hline PL2 & 0.84 & & \\
\hline PL3 & 0.56 & & \\
\hline PL4 & 0.79 & & \\
\hline PL5 & 0.76 & & \\
\hline Factor 3. Information management (0.94) & & 0.94 & 0.80 \\
\hline INFO1 & 0.91 & & \\
\hline INFO2 & 0.92 & & \\
\hline INFO3 & 0.88 & & \\
\hline INFO4 & 0.87 & & \\
\hline Factor 4. Monitoring (0.90) & & 0.90 & 0.70 \\
\hline MON1 & 0.78 & & \\
\hline MON2 & 0.82 & & \\
\hline MON3 & 0.88 & & \\
\hline MON4 & 0.86 & & \\
\hline Factor 5. Debugging (0.78) & & 0.77 & 0.53 \\
\hline DEB1 & 0.69 & & \\
\hline DEB2 & 0.76 & & \\
\hline DEB3 & 0.74 & & \\
\hline Factor 6. Evaluation (0.89) & & 0.89 & 0.67 \\
\hline EVA1 & 0.84 & & \\
\hline EVA2 & 0.89 & & \\
\hline EVA3 & 0.86 & & \\
\hline EVA4 & 0.68 & & \\
\hline Cronbach's alpha for the total item is 0.96 & & & \\
\hline
\end{tabular}

$\overline{\mathrm{SFL}}=$ standardized factor loading; $\mathrm{CR}=$ construct reliability; $\mathrm{AVE}=$ average variance extracted

Table 3 shows that the estimated loading factor values exceed the recommended values. This, therefore, means each observed variable has a good correlation to the construct [39]. INFO2 has the highest correlation of 0.92 to the Information management construct, and PL3 has the lowest correlation of 0.56 to the Planning construct. The CR value describes the extent to which the observed variable represents the construct, and the AVE value reflects the total number of variants in the observed variable described by the construct/latent variable [21], [30]. Empirical data show that the CR and AVE values for all constructs exceed the criteria used. The CR value is in the range of 0.75-0.94, and the AVE value is in the range of 0.52-0.80. This finding complements convergent validity information that has not been reported in similar studies [8], [11], [17]. Therefore, we conclude that HeTMAI has sufficient and acceptable evidence of convergent validity.

\subsection{Discriminant validity}

In the CFA, the discriminant validity of the HeTMAI model can be investigated by comparing the correlation between the two constructs against the AVE estimate [21]. The HeTMAI discriminant validity is shown in Table 4. Table 4 shows that all the estimated AVE values are more significant than squared correlation between constructs. This is an indication of a strong relationship between the constructs in HeTMAI and the indicators themselves. In summary, it provides sufficient evidence that the HeTMAI constructs are different from one another.

Table 4. Discriminant validity of HeTMAI

\begin{tabular}{lcccccc}
\hline \multicolumn{1}{c}{ Dimension } & 1 & 2 & 3 & 4 & 5 & 6 \\
\hline Knowledge of cognition & $0.62^{\mathrm{a}}$ & & & & & \\
Planning & 0.57 & $0.58^{\mathrm{a}}$ & & & & \\
Information management & 0.44 & 0.34 & $0.80^{\mathrm{a}}$ & & & \\
Monitoring & 0.53 & 0.56 & 0.41 & $0.70^{\mathrm{a}}$ & & \\
Debugging & 0.56 & 0.52 & 0.32 & 0.34 & $0.53^{\mathrm{a}}$ & \\
Evaluation & 0.53 & 0.57 & 0.42 & 0.57 & 0.42 & $0.67^{\mathrm{a}}$ \\
\hline
\end{tabular}

Heat and temperature metacognition awareness inventory: A confirmatory ... (Moh. Irma Sukarelawan) 


\subsection{Reliability}

Reliability refers to the extent to which the score on an instrument or test is free from measurement errors and ensures consistency [39]. HeTMAI reliability was determined through the Cronbach's alpha coefficient, and the largest value was found with information management at 0.94 while the lowest was observed with Debugging at 0.78 and Cronbach's alpha for the total item was 0.96. These values are satisfactory based on the proposed standard values (>0.70) [21], [31], [36]. Therefore, HeTMAI can be accepted as a measuring tool that has adequate reliability.

Thus, the six factors of metacognition awareness of heat and temperature material, theoretically, support the factor structure as reported in previous studies [8], [11], [18], [19]. This study is significant because it has provided sufficient evidence of the validity and reliability of HeTMAI. This inventory has been designed to provide specific information related to students' metacognition awareness. For example, to see students' strengths or weaknesses in using temperature-free diagrams when solving black principle questions. Educators can use this information as a guide for evaluating the effectiveness of the designed learning strategies [8].

However, the results of this study are limited to public school students. Validation of inventories uses an analytical approach. We suggest further research to consider the diversity of the respondents' schools. For example, respondents come from private schools or religion-based schools. The Rasch model can be an alternative analysis. The Rasch model can provide more comprehensive information. For example, reviewing how the interaction between items and persons, the Likert scale function used, the items' bias to the attributes of the respondents, and the distribution of the difficulty level of the items [40], [41].

\section{CONCLUSION}

The Heat and Temperature Metacognition Awareness Inventory (HeTMAI) is validated in this study. Six HeTMAI factors show good characteristics as an inventory. The four GOF indices of the CFA results support the six-factor HeTMAI structure's suitability to the conceptual model. The value of $\chi 2 / \mathrm{df}=670.63 / 284=2.36, \mathrm{CFI}=0.97, \mathrm{TLI}=0.97$, and $\mathrm{SRMR}=0.06$. The other analysis results provide evidence that HeTMAI has sufficient convergent and discriminant validity and reliability to measure students' metacognition awareness. SLF, CR, and AVE parameters have values that exceed predefined criteria. The AVE value is greater than the squared correlation of the two constructs, while the Cronbach's alpha coefficient was 0.96. Educators can use this inventory to map students' metacognitive awareness profiles with the results applied to design the best learning activities, evaluate existing programs to optimize students' problem-solving abilities, and assess curriculum implementation for education policymakers in Indonesia.

\section{ACKNOWLEDGEMENTS}

Research and Community Services Institute of Universitas Ahmad Dahlan (LPPM-UAD) has funded this research based on research contract Number: PDP-075/SP3/LPPM-UAD/2020.

\section{REFERENCES}

[1] S. Khan, The One World Schoolhouse: Education Reimagined. New York, NY: Twelve, 2012.

[2] L. M. Mendez Hinojosa, M. C. Rodriguez, and C. A. Ortiz Paez, "Measurement of Metacognition: Adaptation of Metacognitive State Inventory in Spanish to Mexican University Students," European Journal of Educational Research, vol. 9, no. 1, pp. 413-421, Jan. 2020.

[3] Sriyanto and M. I. Sukarelawan, "Mapping of Profile Students' Metacognitive Awareness in Yogyakarta, Indonesia," Journal of Research and Physics Education Research, vol. 6, no. 2, pp. 56-62, Oct. 2019.

[4] S. A. Tachie, "Meta-cognitive Skills and Strategies Application: How this Helps Learners in Mathematics ProblemSolving," Eurasia Journal of Mathematics, Science and Technology Education, vol. 15, no. 5, pp. 1-12, 2019.

[5] Y. Coşkun, "A Study on Metacognitive Thinking Skills of University Students," Journal of Education and Training Studies, vol. 6, no. 3, pp. 38-46, Feb. 2018.

[6] F. Cubukcu, "Metacognition in the Classroom," Procedia - Soc. Behav. Sci., vol. 1, no. 1, pp. 559-563, 2009.

[7] B. Kim, B. Zyromski, M. Mariani, S. M. Lee, and J. C. Carey, "Establishing the Factor Structure of the 18-Item Version of the Junior Metacognitive Awareness Inventory," Measurement and Evaluation in Counseling and Development, vol. 50, no. 1-2, pp. 48-57, Apr. 2017.

[8] G. Taasoobshirazi, M. Bailey, and J. Farley, "Physics Metacognition Inventory Part II: Confirmatory Factor Analysis and Rasch Analysis," Int. J. Sci. Educ., vol. 37, no. 17, pp. 2769-2786, Nov. 2015

[9] B. Çetin, "Metacognition and Self-Regulated Learning in Predicting University Students' Academic Achievement in Turkey," Journal of Education and Training Studies, vol. 5, no. 4, pp. 132-138, Mar. 2017.

[10] A. Zohar and S. Barzilai, "A Review of Research on Metacognition in Science Education: Current and Future Directions," Studies in Science Education, vol. 49, no. 2, pp. 121-169, 2013. 
[11] G. Taasoobshirazi and J. Farley, "Construct Validation of the Physics Metacognition Inventory," International Journal of Science Education, vol. 35, no. 3, pp. 447-459, 2013.

[12] L. Mihalca, C. Mengelkamp, and W. Schnotz, "Accuracy of metacognitive judgments as a moderator of learner control effectiveness in problem-solving tasks," Metacognition and Learning, vol. 12, no. 3, pp. 357-379, 2017.

[13] G. M. Harrison and L. M. Vallin, "Evaluating the metacognitive awareness inventory using empirical factorstructure evidence," Metacognition and Learning, vol. 13, no. 1, pp. 15-38, 2018.

[14] M. Asy'ari, M. Ikhsan, and Muhali, "The effectiveness of inquiry learning model in improving prospective teachers' metacognition knowledge and metacognition awareness," Int. J. Instruction, vol. 12, no. 2, pp. 455-470, 2019.

[15] M. T. H. Chi, "Two Approaches to the Study of Experts' Characteristics," in K. A. Ericsson, R. R. Hoffman, A. Kozbelt, and A. M. Williams, Eds., The Cambridge Handbook of Expertise and Expert Performance. New York: Cambridge University Press, 2006, pp. 21-30.

[16] K. Craig, D. Hale, C. Grainger, and M. E. Stewart, "Evaluating metacognitive self-reports: Systematic reviews of the value of self-report in metacognitive research," Metacognition and Learning, vol. 15, no. 2, pp. 155-213, 2020.

[17] H. Haeruddin, Z. K. Prasetyo, and S. Supahar, "The development of a metacognition instrument for college students to solve physics problems," Int. J. Instruction, vol. 13, no. 1, pp. 767-782, 2020.

[18] Z. K. Ünlü and İ. Dökme, "Adaptation of physics metacognition inventory to Turkish," International Journal of Assessment Tools in Education, vol. 6, no. 1, pp. 125-137, Mar. 2019.

[19] Haeruddin, Z. K. Prasetyo, Supahar, E. Sesa, and G. Lembah, "Psychometric and structural evaluation of the physics metacognition inventory instrument," European J. Educ. Res., vol. 9, no. 1, pp. 215-225, 2020.

[20] I. Aykutlu, S. Bezen, and C. Bayrak, "An assessment of high school students' conceptual structures of heat and temperature through concept maps," AIP Conference Proceedings, vol. 1815, no. 1, 2017, pp. 1-4.

[21] J. F. Hair, W. C. Black, B. J. Babin, and R. E. Anderson, Multivariate Data Analysis, 7th ed. British: Pearson Education Limited, 2014.

[22] S. W. Huck, Reading Statistics and Research, 6th ed. Boston: Pearson, 2012.

[23] J. Syahfitri, H. Firman, S. Redjeki, and S. Sriyati, "Development and validation of critical thinking disposition test in biology," Int. J. Instruction, vol. 12, no. 4, pp. 381-392, 2019.

[24] Y.-J. Son and M. H. Won, "Psychometric Validation of the Korean Version of the 9-Item European Heart Failure Self-Care Behaviour Scale," Evaluation \& the Health Professions, vol. 43, no. 1, pp. 33-40, Dec. 2018, doi: $10.1177 / 0163278718817946$

[25] G. Modarresi and E. Javan, "Construction and validation of foreign language learners' dropout questionnaire," Int. J. Instruction, vol. 11, no. 4, pp. 425-444, 2018

[26] G. Gürkan and S. Kahraman, "Development of an attitude scale to measure attitudes towards organ transplantation and donation of preservice teachers," Journal of Baltic Science Education, vol. 17, no. 6, pp. 1005-1016, 2018.

[27] J. Appianing and R. N. Van Eck, "Development and Validation of the Value-Expectancy STEM Assessment Scale for Students in Higher Education," International Journal of STEM Education, vol. 5, no. 1, pp. 1-16, Dec. 2018.

[28] E. Ad'hiya and E. W. Laksono, "Development and validation of an integrated assessment instrument to assess students' analytical thinking skills in chemical literacy," Int. J. Instruction, vol. 11, no. 4, pp. 241-256, 2018.

[29] R. L. Worthington and T. A. Whittaker, "Scale Development Research: A Content Analysis and Recommendations for Best Practices," The Counseling Psychologist, vol. 34, no. 6, pp. 806-838, 2006.

[30] R. B. Kline, Principles and practices of structural equation modelling, 4th ed. New York: The Guilford Press, 2016.

[31] Setyo H. Wijanto, Structural Equation Modeling with Lisrel 8.8: Concepts and Tutorials, 1st ed. Yogyakarta: Graha Ilmu, 2008.

[32] M. Hanifah et al., "A Confirmatory Factor Analysis of Malaysian Primary School Students' Energy Saving Practices," Journal of Turkish Science Education, vol. 15, no. 3, pp. 51-63, 2018.

[33] S. A. Chamberlin, A. D. Moore, and K. Parks, "Using Confirmatory Factor Analysis to Validate the Chamberlin Affective Instrument for Mathematical Problem Solving with Academically Advanced Students," British Journal of Educational Psychology, vol. 87, no. 3, pp. 422-437, Sep. 2017.

[34] Y. M. Lee, J.-E. Song, C. Park, and Y.-J. Son, "Psychometric Evaluation of the Korean Version of Patient-Centered Care Scale for Hospital Nurses," Evaluation \& the Health Professions, vol. 42, no. 3, pp. 344-365, Sep. 2018.

[35] J. Pallant, SPSS survival manual: A step by step guide to data analysis using SPSS, 4th ed. McGraw-Hill, 2010.

[36] D. F. Polit and C. T. Beck, Nursing research: Generating and assessing evidence for nursing practice, 10th ed. Philadelphia: Wolters Kluwer, 2017.

[37] A. S. Beavers, J. W. Lounsbury, J. K. Richards, S. W. Huck, G. J. Skolits, and S. L. Esquivel, "Practical Considerations for Using Exploratory Factor Analysis in Educational Research," Practical Assessment, Research and Evaluation, vol. 18, no. 6, pp. 1-13, 2013.

[38] E. B. K. Demir and G. F. Gündüz, "Development of a scale for students in evaluating 2017 information technology and software curriculum," Int. J. Instruction, vol. 12, no. 4, pp. 313-330, 2019.

[39] L. R. Price, Psychometric Methods: Theory Into Practice. New York: The Guilford Press, 2017.

[40] T. G. Bond and C. M. Fox, Applying the Rasch model: Fundamental measurement in the human sciences, 3rd ed. New York, NY: Routledge, 2015.

[41] W. Sumintono, Bambang, and Widhiarso, Rasch modeling application in educational assessment. Cimahi: Trim Komunikata, 2015. 